\title{
Malaysian Fournal of Microbiology \\ Biosorption and proteomic analysis of an encapsulated endophytic heavy-metal resistant Pestalotiopsis sp.
}

\author{
Jenny Choo¹, Norasfaliza Rahmad², Jameel R. Al-Obaidi², Aazani Mujahid ${ }^{3}$, LikFong Ting ${ }^{1}$, and Moritz Müller ${ }^{1 *}$ \\ ${ }^{1}$ Swinburne University of Technology, Sarawak Campus, 93350 Kuching, Sarawak, Malaysia. \\ ${ }^{2}$ Agro-Biotechnology Institute, Malaysia (ABI), National Institutes of Biotechnology Malaysia Ibu-Pejabat MARDI, 43400 \\ Serdang, Selangor, Malaysia. \\ ${ }^{3}$ University of Sarawak (UNIMAS), 94300 Kota Samarahan, Sarawak, Malaysia.
}

Email: mmueller@swinburne.edu.my

Received 24 January 2018; Received in revised form 28 November 2018; Accepted 10 July 2019

\begin{abstract}
Aims: A study on biosorption ability using encapsulated endophytic fungi has been carried out to investigate its biosorption potential in removing heavy metals. Biosorption has emerged as an alternative bioremediation process to remove and sequester heavy metal ions from polluted water. An endophytic Pestalotiopsis sp. (isolated from Nypa fruticans) was found to be able to resist copper $(\mathrm{Cu})$, chromium $(\mathrm{Cr})$, lead $(\mathrm{Pb})$ and zinc $(\mathrm{Zn})$ up to $1,000 \mathrm{ppm}$ and thus the aim of this study was to investigate the biosorption ability using encapsulated live and dead Pestalotiopsis sp. biomass (at $\mathrm{pH} 4-6$ ) to remove heavy metals. Additionally, a proteomic study was conducted to investigate down- and up-regulation expression levels of proteins under the treatment of the heavy metals.

Methodology and results: Encapsulated live fungal biomass displayed higher efficiency in removing chromium at $\mathrm{pH} 5$ and 6 , while both encapsulated live and dead biomass were able to remove lead at $\mathrm{pH} 4$ and 5 and copper at $\mathrm{pH} 5$. Five (5) proteins of interest were identified via MALDI-ToF analysis. Among the proteins identified, multidrug resistance protein (MRP homolog) was up-regulated in the presence of lead.

Conclusion, significance and impact of study: The data obtained in this study provides an initial understanding of the biosorptive and defensive mechanisms of Pestalotiopsis sp. under heavy metal stress.
\end{abstract}

Keywords: Biosorption, heavy-metal resistant, proteomic, encapsulation, live and dead biomass

\section{INTRODUCTION}

In order to treat heavy metal pollution in aqueous solution, biosorption has been highlighted as an attractive alternative bioremediation process to solve this environmental issue. It acts by binding and sequestering metals through the use of biological biomass for the removal of metal ions from dilute aqueous solution (Skowronski et al., 2001). There are numerous advantages of biosorption over conventional treatments which include low cost, high efficiency in removing pollutants from dilute solution, minimization of chemical and biological sludge, regeneration of biosorbent, and requires no additional nutrient with the possibility of metal recovery (Arıca et al., 2001; Kratochvil and Volesky, 1998).

Several types of biomass can be used and serve as potential biosorbents for the adsorption of heavy metal ions. Wang and Chen (2009) discussed three (3) main groups of potential biosorbents: bacteria (Gram positive and Gram negative), fungi (filamentous fungi and yeast) and algae. Microbes isolated from polluted environment have been studied as potential biosorbents (Iram et al., 2012) and it has been reported that those isolated microbes (Sargassum natans, Bacillus subtilis, Aspergillus niger and Saccharomyces cerevisiae) have successfully adapted and survived at the contaminated environment and were thus able to resist pollutants such as heavy metals. Several studies have been undertaken on agricultural waste materials such as activated sludge, rice husk, egg shell, peat moss, hazelnut shell, sunflower and cotton stalk, waste tea leave and orange and banana peel ( Tee and Khan, 1988; Cimino et al., 2000; Annadurai et al., 2002; Chuah et al., 2005; Al-Qodah, 2006; Hashem, 2006; Farooq et al., 2010). Farooq et al. (2010) also highlighted the use of wheat-based biosorbent such as straw and bran from wheat. However, the use of endophytic fungi as potential biosorbents has not been 
widely studied. Hence, in this present study, we aim to explore the potential of identified heavy-metal resistant endophytic fungus Pestalotiopsis sp. on the biosorption approach by undertaking investigation against various $\mathrm{pH}$ condition with encapsulated live and dead fungal biomass to explore and understand its biosorptive abilities. Pestalotiopsis sp. isolated from Nypa fruticans from wetlands of Sarawak has been identified to be able to resist heavy metal ions $(\mathrm{Cu}, \mathrm{Cr}, \mathrm{Pb}$ and $\mathrm{Zn})$ up to 1000 ppm (Choo et al., 2015) which motivated our study to assess biosorptive abilities of this endophytic fungus. Members of the Pestalotiopsis have also shown potential to be used as biofuel feedstock (Sia et al., 2017) and been able to degrade polyurethane polymers (Bong et al., 2017).

Firstly, encapsulation of biomass can further enhance the biosorption process as free cells are not suitable in columns for providing high efficiency in removing metal ions (Veglio and Beolchini, 1997; Vijayaraghavan and Yun, 2008). This is due to the cells' low density and size which tend to plug the bed and result in large drops in pressure. Encapsulation of biomass has also been utilized in conventional reactor technology like the large packed and fluidized bed reactor systems (Gadd \& White, 1993). Through encapsulation, biomass is converted into spherical shape and thus enabled to be used like the conventional adsorbents. There are several encapsulation techniques available for biomass including alginate, polyacrylamide, polyvinyl alcohol, polysulfone, silica gel, cellulose and glutaraldehyde (Park et al., 2010) and the present study aims to encapsulate heavy-metal resistant Pestalotiopsis sp. (Choo et al., 2015) and further investigate the efficiency of dead and live encapsulated Pestalotiopsis sp. biomass on its biosorption abilities.

Secondly, biosorption process is mainly affected by $\mathrm{pH}$, initial metal concentration, temperature, ionic strength, biomass concentration and size, and agitation speed (Park et al., 2010). $\mathrm{pH}$ is considered to be the most important parameter in the biosorption process as the difference in $\mathrm{pH}$ affects the activity of functional groups on the cell wall of the biomass, the solution chemistry of the metals and the competition of the metallic ions (Park et al., 2010). As an example, several studies suggest that a $\mathrm{pH}$ of 4-6 is significantly more favorable for adsorption of lead ions (Yetis et al., 2000; Yan and Viraraghavan, 2003; Martínez et al., 2006; Jonglertjunya, 2008). Biomass concentration also affects the process as the lower the concentration, the higher the interference for binding sites. However, temperature does not seem to influence the biosorption process in the range of $20-35^{\circ} \mathrm{C}$ (Aksu et al., 1992; Veglio and Beolchini, 1997). Therefore, in this study, we focus on investigating the potential effect of different $\mathrm{pH}$ conditions towards the biosorption efficiency of the encapsulated Pestalotiopsis sp.

Thirdly, several studies have shown that heavy metals affect the intracellular activities of cells (Ye et al., 1997). A study by Gardes and Bruns (1993) showed that heavy metals such as copper and cadmium do not only bind to aromatic amino acid residues in enzyme molecules, but also induce oxidative stress related to the production of reactive oxygen, such as hydroxyl and or superoxide radicals, and eventually cause oxidative damage of proteins. The enzymes which are released into the extracellular environment are often faced with high concentrations of heavy metals due to the fact that they are not protected by the cell-associated metal detoxification mechanisms (Ye et al., 1997). Hence to further understand the biosorptive mechanism, biosorption experiments were coupled in this study with proteomic analysis to provide insights into the intracellular mechanisms of the heavy-metal resistant Pestalotiopsis $\mathrm{sp}$.

\section{MATERIALS AND METHODS}

\section{Encapsulation of fungal biomass into calcium alginate beads}

The fungal culture Pestalotiopsis sp. (Choo et al., 2015) was obtained from the stock culture maintained on Potato Dextrose slants at $\mathrm{pH}$ 5.6. The fungal culture was cut aseptically and transferred onto sterile $100 \mathrm{~mL}$ of Potato Dextrose Broth (PDB) in a $250 \mathrm{~mL}$ conical flask and incubated for 5 days at $25^{\circ} \mathrm{C}$. After incubation period, the fungal biomass with spherical clumps were harvested and filtered from the growth medium. The clump biomass was homogenized with a commercial blender to destroy cell aggregates (Arıca et al., 2001). Based on a study by Arıca et al. with modification, $2 \mathrm{~g}$ of alginate in $100 \mathrm{~mL}$ sterilized distilled water was used to prepare $2 \%$ alginate solution and mixed with $0.5 \mathrm{~g}$ live fungal biomass. A $5 \mathrm{~mL}$ hypodermic syringe was used to dispense the alginate fungal biomass mixture into $3 \% \mathrm{CaCl}_{2}$. The mixture was stirred to prevent aggregation of the fungal calcium alginate beads. The mixture was kept for $2 \mathrm{~h}$ at $4{ }^{\circ} \mathrm{C}$ to form beads and the beads were then filtered and rinsed thoroughly with sterile distilled water and air dried. For the preparation of encapsulated dead fungus, the fungal biomass was filtered and autoclaved at $121{ }^{\circ} \mathrm{C}$ for $15 \mathrm{~min}$ before being entrapped. The calcium alginate beads with encapsulated live and dead fungus were stored in $5 \mathrm{mM}$ of $\mathrm{CaCl}_{2}$ solution at $4{ }^{\circ} \mathrm{C}$ until further use.

\section{Determination of biosorption efficiency using encapsulated fungal culture under different $\mathrm{pH}$ condition}

Biosorption of $\mathrm{Cu}, \mathrm{Cr}, \mathrm{Pb}$, and $\mathrm{Zn}$ ions by encapsulated live and dead fungal biomass in calcium alginate beads from aqueous solution was investigated in biosorptionequilibrium experiments. The effects of the medium $\mathrm{pH}$ of $\mathrm{Cu}, \mathrm{Cr}, \mathrm{Pb}$, and $\mathrm{Zn}$ ions on the biosorption rate and capacity were studied. The effect of $\mathrm{pH}$ on the biosorption rate of the encapsulated fungal beads was investigated in the $\mathrm{pH}$ range of 4-6 for $\mathrm{Cr}$ and $\mathrm{Zn}$; $\mathrm{pH}$ of 4 and 5 for $\mathrm{Cu}$ and $\mathrm{Pb}$ (adjusted with $\mathrm{HCl}$ or $\mathrm{NaOH}$ at the beginning of the experiment) at $25^{\circ} \mathrm{C}$. $\mathrm{Cu}, \mathrm{Cr}, \mathrm{Pb}$ and $\mathrm{Zn}$ ions concentration in each solution was prepared in 1.0, 3.0 and $5.0 \mathrm{ppm}$ with distilled water $(10 \mathrm{~mL})$. 
Based on several studies on the findings of the optimum $\mathrm{pH}$ condition, $\mathrm{pH}$ range of 4-6 seems to be a favorable $\mathrm{pH}$ condition for adsorption of lead ions (Yetis et al., 2000; Yan and Viraraghavan, 2003; Martínez et al., 2006; Jonglertjunya, 2008). Hence, the low pH range was selected in this study. However, the lead ions adsorption above $\mathrm{pH} 6$ was not included as the lead acetate ion was observed to precipitate at $\mathrm{pH} 6$. Lead carbonate that was used in this study could not be dissolved in water. Thus, acetic acid was used to react with the lead carbonate for making it soluble in water. This attributes to the fact that lead carbonate is insoluble in neutral water and will only dissolve in acids or alkaline water (Carr et al., 1995). Hence, in order to dissolve lead carbonate in water for this study, acetic acid was used to dissolve lead carbonate to produce lead acetate. Acetic acid will dissolve lead carbonate by the following reaction to produce soluble lead acetate, water and carbon dioxide.

$\mathrm{PbCO}_{3}+2 \mathrm{CH}_{3} \mathrm{COOH} \mathrm{Pb}\left(\mathrm{CH}_{3} \mathrm{COO}\right)_{3}+\mathrm{H}_{2} \mathrm{O}+\mathrm{CO}_{2}$

Biosorption of $\mathrm{Cu}, \mathrm{Cr}, \mathrm{Pb}$ and $\mathrm{Zn}$ ions in aqueous solutions were studied in batch systems and measured after incubation period of approximately $30 \mathrm{~min}$. Biosorption process is a rapid process and it happens rapidly as $85 \%$ of the process is reported to take place in the first half an hour (Bayramoğlu et al., 2002). Thus, the experiment was designed to measure the removal efficiency after $30 \mathrm{~min}$ of immobilized calcium alginate beads incubation with the metal ions.

The concentrations of the ions in these phases were measured using Atomic Absorption Spectrophotometer (AAS), Thermo Fisher Scientific iCE 3000 Series AA. The working wavelength for $\mathrm{Cr}, \mathrm{Zn}, \mathrm{Cu}$, and $\mathrm{Pb}$ ions were $357.9,213.9,324.8$ and $217.0 \mathrm{~nm}$ respectively (Kojuncu et al., 2004). The instrument response was checked with $3.0 \mathrm{ppm}$ of ion solution standard for each heavy metal. For each triplicates of data, standard statistical methods were used to determine the mean values and standard deviations. The removal efficiency, $R$, of metal ions adsorbed per unit on both alginate entrapped live and dead fungal biomass was obtained by using the following expression (Hao and Hou, 2013):

$$
R=\frac{\mathrm{Co}-\mathrm{Ct}}{\mathrm{Ct}} \times 100 \%
$$

Where,

$\mathrm{Co}=$ initial concentration (ppm)

$\mathrm{Ct}=$ concentration of metal ions (ppm) at time $\mathrm{t}(\mathrm{min})$

\section{Proteomics study}

Fungal preparation and growth condition

Prior to protein extraction, heavy-metal resistant Pestalotiopsis sp. was cultured and incubated in Potato Dextrose Agar supplemented with 1000 ppm of $\mathrm{Cr}, \mathrm{Pb}$, $\mathrm{Cu}$, and $\mathrm{Zn}$ respectively, as well as preparation of control samples for 3 days at room temperature. After 3 days, the fungus was inoculated into $100 \mathrm{~mL}$ Potato Dextrose Broth in a $250 \mathrm{~mL}$ Erlenmeyer flask for 4 weeks at room temperature. After the incubation, fungal biomass obtained was filtered using Whatman no. 5 filter paper. The filtered fungal biomass was then kept in $50 \mathrm{~mL}$ centrifuge tubes for subsequent proteomics studies.

\section{Protein extraction}

The mycelia of Pestalotiopsis $\mathrm{sp}$. were harvested by filtration and centrifuged at $3,000 \mathrm{~g}$ for $15 \mathrm{~min}$ at $4{ }^{\circ} \mathrm{C}$. After centrifugation, the broth was discarded and miliQ water was added. The steps were repeated twice to obtain the fungal biomass. The fungal biomass was frozen in liquid nitrogen to lyophilise the cells. The mycelia were grounded using a mortar and pestle in liquid nitrogen to obtain dry mycelia and kept at $-80{ }^{\circ} \mathrm{C}$. The dried mycelia powder $(1 \mathrm{~g})$ was subjected to the TCA/acetone method of protein, according to Sanger et al., (1977) with modification. $1 \mathrm{~g}$ of mycelia powder was added with $1.8 \mathrm{~mL}$ of cold TCA-2ME-acetone solution and was mixed and stored at $-20^{\circ} \mathrm{C}$ for $1 \mathrm{~h}$. Then, the mixture was centrifuged for $10 \mathrm{~min}$ at $10,000 \mathrm{~g}$ at $4{ }^{\circ} \mathrm{C}$. Once centrifuged, the supernatant was discarded. The pellet obtained was resuspended in cold $1.8 \mathrm{~mL}$ rinsing solution $\left(0.07 \% 2 \mathrm{ME}(\mathrm{v} / \mathrm{v})\right.$ in cold acetone) and stored at $-20{ }^{\circ} \mathrm{C}$ for $1 \mathrm{~h}$. After incubation, the resuspended pellet was centrifuged for $15 \mathrm{~min}$ at $10,000 \mathrm{~g}$ and the supernatant was discarded twice. The pellet obtained was dried using SpeedVas for $30 \mathrm{~min}$. The technical triplicates were pooled and the final pellet was then resuspended with the lysis buffer (8M urea solution; $4 \%$ (w/v) CHAPS; $2 \%(v / v)$ IPG buffer; $40 \mathrm{mM}$ DTT) and vortexed for $1 \mathrm{~min}$. After vortex, the mixture was centrifuged for $15 \mathrm{~min}$ at $10,000 \mathrm{~g}$ and the supernatant was collected twice. The protein content was quantified using the Bradford method with BSA as the standard maker Rizzo and Buck (2012).

\section{SDS-PAGE two-dimensional analysis}

For 2-DE analysis, the nonlinear IPG strips $(11 \mathrm{~cm}, \mathrm{pH} 3$ 10; Bio-Rad) were rehydrated for 18 hours with $50 \mu \mathrm{g}$ mycelium protein in $250 \mu \mathrm{L}$ of rehydration buffer (8 M urea; 4\% (w/v) CHAPS; 2\% (v/v) IPG buffer; 40 mM DTT; $0.002 \%$ of $1 \%$ bromophenol blue solution). The IEF strips were loaded onto the Bio-Rad Protean IEF Cell system and the Isoelectric Focusing (IEF) was performed following standard protocols based on Biored Handbook (IEF Protocol) with modifications: $500 \mathrm{~V}$ for $2 \mathrm{~h}, 1,000 \mathrm{~V}$ for $1 \mathrm{~h}, 8,000 \mathrm{~V}$ for $1 \mathrm{~h}$, and finally focused on $29,000 \mathrm{Vh}$ at $8,000 \mathrm{~V}$. The strips were run at $50 \mathrm{~mA}$. Triplicates IEF strips were run for each heavy-metal resistant mycelia protein. The strips were then stored at $-20^{\circ} \mathrm{C}$ prior to 2-D gel electrophoresis. Before running 2-D gel electrophoresis, the strips were thawed and alkylated (based on GE Healthcare 2D SDS PAGE Handbook) with SDS Equilibration 1 solution (50 mM of Tris-HCL pH 8.8; $6 \mathrm{M}$ urea; $30 \%(\mathrm{v} / \mathrm{v})$ of $37 \%$ glycerol; $2 \%(\mathrm{w} / \mathrm{v})$ of SDS; $0.002 \%(\mathrm{w} / \mathrm{v})$ of bromophenol blue; $50 \mathrm{mg}$ DTT) and SDS Equilibration 2 solution (50 mM of Tris-HCL pH 8.8; $6 \mathrm{M}$ 
urea; $30 \%(v / v)$ of $37 \%$ glycerol; $2 \%(w / v)$ of SDS; $0.002 \%$ $(\mathrm{w} / \mathrm{v})$ of bromophenol blue; $125 \mathrm{mg}$ IAA). The strips were alkylated for $15 \mathrm{~min}$ in each SDS equilibration solution. For the 2-D gel electrophoresis, the SE 600 Ruby Standard Dual Cooled Vertical Unit system was used according to the Mini-PROTEAN Tetra Cell Instruction, Bio-Rad. The SDS-PAGE was performed using precast $12 \%$ resolving gel $(30 \%$ acrylamide/bis solution; $1.5 \mathrm{M}$ Tris-HCL pH 8.8; $10 \%$ (w/v) SDS; $10 \%$ (w/v) APS; 0.05\% TEMED and deionized water). The 10X electrode running buffer, pH 8.3 (0.25M Tris-Base; 1.92M glycine; $1 \%(\mathrm{w} / \mathrm{v})$ SDS; deionized water) was prepared for the gel electrophoresis. Once the IEF strip was placed in the SE 600 Ruby system with the BSA protein marker, the strips were overlay and sealed with agarose sealing solution (0.5 g agarose; $1 \times$ running buffer; $200 \mu \mathrm{L}$ bromophenol blue). The gel was allowed to polymerize for $1 \mathrm{~h}$. After polymerised, the gel was run for $15 \mathrm{~min}$ at $10 \mathrm{~mA}$ and 20 $\mathrm{mA}$ for $3 \mathrm{~h}$ until the dye reached the bottom of the gel.

After 2-D gel electrophoresis, the gels were stained using the silver staining method (Kingsmore and Saunders, 2011) with modification. The gel was stained in fixation solution ( $50 \%$ ethanol absolute; $2.5 \%$ acetic acid absolute in $50 \mathrm{~mL}$ deionized water) for $30 \mathrm{~min}$. After fixation, the gel was sensitized in infiltrating solution $(7.5 \%$ ethanol absolute; $3.4 \mathrm{~g}$ sodium acetate; $0.1 \mathrm{~g}$ sodium thiosulfate in $50 \mathrm{~mL}$ deionized water). The gel was then washed with deionized water 3 times for 5 min each. After washing, silver solution $(0.1 \%$ silver nitrate and $10 \mu \mathrm{L}$ formaldehyde in $50 \mathrm{~mL}$ deionized water) was added to the gel for $20 \mathrm{~min}$. After discarding the silver solution, the staining solution $(1.25 \mathrm{~g}$ sodium carbonate and $5 \mu \mathrm{L}$ formaldehyde in $50 \mathrm{~mL}$ deionized water) was added to the gel with gentle agitation until protein spots appeared. Protein spots appeared approximately after $10 \mathrm{~min}$. After protein spots appeared on the gel, the gel was added with stop solution $\left(0.73 \mathrm{~g}\right.$ EDTA. $\mathrm{Na}_{2} \mathrm{H}_{2} \mathrm{O}$ in $50 \mathrm{~mL}$ deionized water) for $10 \mathrm{~min}$. The gel was then washed with deionized water for 3 times for 5 min each and was kept in distilled water prior to image capturing of gel.

The gel images were captured using the GS-800 Calibrated Densitometer. The images were analysed using the PDQuest ${ }^{\mathrm{TM}}$ software (Bio-Rad) by using 2-fold over background as criteria for detecting the presence or absence of the protein spots on the heavy-metal resistant protein and control gel. Manual alignment of the gel was conducted to increase the reliability of the matching protein spots which were present or absent in all triplicates of the heavy-metal resistant protein gel against the control gel with Anova p-value of $<0.05$.

\section{Analysis by MALDI-ToF}

Prior to MALDI-ToF analysis, the spots of interest were excised and placed it in a $1.5 \mathrm{~mL}$ centrifuge tube. The gel pieces were washed with $150 \mu \mathrm{L}$ of $100 \mathrm{mM} \mathrm{NH}_{4} \mathrm{HCO}_{3}$ for 10 min. After removing the $\mathrm{NH}_{4} \mathrm{HCO}_{3}$ solution, destaining solution $\left(0.045 \mathrm{~g}\right.$ of $15 \mathrm{mM} \mathrm{K}_{3} \mathrm{Fe}(\mathrm{CN})_{6}, 0.079 \mathrm{~g}$ of $50 \mathrm{mM}$ $\mathrm{Na}_{2} \mathrm{~S}_{2} \mathrm{O}_{3}$ in $10 \mathrm{~mL}$ water) was added and left for incubation for $15 \mathrm{~min}$. The step was repeated twice. The protein was reduced by adding $150 \mu \mathrm{L}$ of $10 \mathrm{mM}$ DTT in $100 \mathrm{mM} \mathrm{NH} \mathrm{HCO}_{3}$ and incubated for $30 \mathrm{~min}$ at $60{ }^{\circ} \mathrm{C}$. The protein was then alkylated with 55mM IAA in $100 \mathrm{mM}$ $\mathrm{NH}_{4} \mathrm{HCO}_{3}$ solution and incubated in the dark for $20 \mathrm{~min}$. The gel pieces were washed with $50 \%$ ACN in $100 \mathrm{mM}$ $\mathrm{NH}_{4} \mathrm{HCO}_{3}$ solution for 20 min for 3 times. The solution was removed and was added with $50 \mu \mathrm{L}$ of $100 \%$ ACN and incubated for $15 \mathrm{~min}$ at room temperature. The pieces of gel were dried with speed vacuum for $15 \mathrm{~min}$. $25 \mu \mathrm{L}$ of $7 \mathrm{ng} / \mu \mathrm{L}$ of trypsin solution was added and incubated overnight at $25^{\circ} \mathrm{C}$. After overnight incubation, the $25 \mu \mathrm{L}$ of $50 \%$ ACN was added and the solution was incubated for $15 \mathrm{~min}$. The solution was then collected into a new tube (tube A) and second extraction of protein was performed with $100 \% \mathrm{ACN}$ in the tube containing the gel pieces and incubated for $15 \mathrm{~min}$. The solution was then transferred into the new tube (tube A). The solution in the tube was dried using speed vacuum. The dried protein was kept at $-80^{\circ} \mathrm{C}$ and was reconstituted by adding in 5 $\mu \mathrm{L}$ of $1.0 \%$ formic acid in water prior to MALDI-ToF analysis. The protein identification was undertaken via MALDI-ToF as described in $\mathrm{Li}$ et al. (2013) with modifications. The generated data files were then sequenced with similarity searches using MASCOT NCBInr database (http://www.matrixscience.com) with default parameters based on peptide mass fingerprinting PMF and MS/MS spectra.

\section{RESULTS AND DISCUSSION}

The concentrations of heavy metal ions $(\mathrm{Cu}, \mathrm{Cr}, \mathrm{Pb}$, and $\mathrm{Zn}$ ) were measured using AAS after an incubation period of 30 min with (a) encapsulated live and (b) dead fungal Pestalotiopsis sp. biomass. Removal efficiencies of $\mathrm{Cr}, \mathrm{Pb}$ and $\mathrm{Cu}$ ions by live and dead fungal biomass are presented in Table 1. Since only $\mathrm{Cr}, \mathrm{Pb}$ and $\mathrm{Cu}$ displayed positive removal, biosorption of $\mathrm{Zn}$ will not be discussed in the following.

\section{Biosorption of chromium ions with encapsulated Ca- alginate fungal biomass}

Based on Table 1, encapsulated live Pestalotiopsis sp. biomass displayed the highest removal efficiency of $\mathrm{Cr}$ ions at $\mathrm{pH} 5$ with $24.54 \%$ while the encapsulated dead fungal biomass at the similar $\mathrm{pH}$ removed $17.26 \%$ of the $\mathrm{Cr}$ ions in solution. Furthermore, a positive removal efficiency of $13.56 \%$ was reported by encapsulated live fungal biomass at $\mathrm{pH} 6$, however the encapsulated dead fungal biomass demonstrated negative removal efficiency. On the other hand, encapsulated dead and live fungal biomass was not able to remove any $\mathrm{Cr}$ ions at $\mathrm{pH} 4$. In this study, the live encapsulated $\mathrm{Ca}$-alginate fungal biomass showed a slightly higher efficiency in removing $\mathrm{Cr}$ ions (Table 1) and this observation is supported by Doshi et al., (2007) who found that live biomass of Spirulina sp. showed a higher efficiency than the dead biomass in adsorbing the $\mathrm{Cr}$ ions. This could be due to the fact that living cells could demonstrate more variety of metal accumulation mechanisms such as extracellular 
Table 1: The removal efficiency (\%) of the encapsulated live and dead fungal biomass towards chromium ion at $\mathrm{pH}$ 4-6; lead and copper ions at $\mathrm{pH} 4$ and 5.

\begin{tabular}{llll}
\hline $\begin{array}{l}\text { Heavy } \\
\text { metal ion }\end{array}$ & $\mathrm{pH}$ & $\begin{array}{l}\text { Type of } \\
\text { biomass }\end{array}$ & $\begin{array}{l}\text { Removal } \\
\text { efficiency (\%) }\end{array}$ \\
\hline Chromium & 4 & Live & NA \\
& 4 & Dead & NA \\
& 5 & Live & 24.54 \\
& 5 & Dead & 17.26 \\
& 6 & Live & 13.56 \\
Lead & 6 & Dead & -1.27 \\
& 4 & Live & 12.96 \\
& 4 & Dead & 45.88 \\
Copper & 5 & Live & 6.057 \\
& 5 & Dead & 17.96 \\
& 4 & Live & NA \\
& 4 & Dead & NA \\
& 5 & Live & 10.28 \\
& 5 & Dead & 14.50 \\
\hline
\end{tabular}

complex formation and transport of metal ions (Mohapatra, 2011). Acidic conditions favour the binding of Chromium towards fungal biomass, with the hdroxyl group found to be the Chromium binding site within a $\mathrm{pH}$ range of 1-5 (Mohanty et al., 2006).

A paired t-test was performed on the triplicate samples of encapsulated Pestalotiopsis sp. biomass tested at $\mathrm{pH} 5$ which shows the highest $\mathrm{Cr}$ ions removal efficiency in this study. The statistical analysis reported that the effect of $\mathrm{pH} 5$ showed significant impact on $\mathrm{Cr}$ ions removal by dead Pestalotiopsis sp. biomass $\left(\mathrm{t}_{(2)}=24.515, p<0.05\right)$ as shown in Table 2. This suggests that $\mathrm{pH} 5$ provide a suitable medium for the removal of $\mathrm{Cr}$ ions by encapsulated dead Pestalotiopsis sp.

Fittingly, similar results were also reported by Lesage et al. (2007) using Aspergillus niger at pH 5.0. The fungal biomass contains chitin and chitosan, which contain $\mathrm{COOH}$ and $-\mathrm{NH}_{2}$ groups that are responsible for the binding of metal ions (Seo et al., 2008). At optimum sorption $\mathrm{pH}$ (acidic), the types of $\mathrm{Cr}$ in the solution are mainly chromic acid, dichromate ion, trichromate and tetrachromate ions. In acidic condition, the surface of the sorbent is protonated and causes a stronger attraction towards the negatively charged $\mathrm{Cr}$ ions. As the $\mathrm{pH}$ increases, the concentration of $\mathrm{OH}^{-}$increases and this eventually results in a negative charged surface of the sorbent, in turn limiting the adsorption of the negatively charged $\mathrm{Cr}$ ions. Several studies have shown that biosorption was higher at even lower $\mathrm{pH}$ conditions (Bai and Abraham, 2001; Ozdemir et al., 2004; Park et al., 2005), however, our results did not confirm this trend for Pestalotiopsis sp. encapsulated in Ca-alginate beads. Instead, neither dead nor alive encapsulated biomass was able to remove $\mathrm{Cr}$ at $\mathrm{pH} 4.0$ (Table 1). This finding could be attributed to the chemical change of Pestalotiopsis sp. due to the hydrolytic activity at higher acid concentrations as reported by Tewari et al., (2005) in the use of Mucor hiemalis. As reported by Congeevaram et al. (2007) and Zhang et al. (2010), the removal of the $\mathrm{Cr}$ ions only showed rapid performance at $\mathrm{pH} 5$, the same trend observed as the Pestalotiopsis sp. used in this experiment. Different adsorbents used will exhibit different adsorption efficiencies and it is important to study and determine the optimum $\mathrm{pH}$ for the various adsorbents towards the removal of $\mathrm{Cr}$ ions. Besides the electrostatic binding of ions, a study undertaken by Park et al. (2005) has reported that the main mechanism of $\mathrm{Cr}$ removal was a redox reaction between $\mathrm{Cr}$ and the dead fungal biomass. This may explain the observed non-removal efficiency recorded in this study.

\section{Biosorption of lead ions using encapsulated Ca- alginate fungal biomass}

For the case of $\mathrm{Pb}$ ions removal, both encapsulated live and dead Pestalotiopsis sp. biomass recorded positive removal efficiency of $\mathrm{Pb}$ ions under $\mathrm{pH} 4$ and 5 . A paired $\mathrm{t}$-test was carried out to study the impact of $\mathrm{pH}$ parameter had on $\mathrm{Pb}$ ions removal and a statistically significant impact of $\mathrm{pH} 5$ on encapsulated dead Pestalotiopsis sp. was reported $(\mathrm{t}(2)=12.865, p<0.05$ in this study (Table $2)$. The finding in this experiment correlates well with other studies which reported an optimum $\mathrm{pH}$ range of 4-6 for adsorption of $\mathrm{Pb}$ ions (Yetis et al., 2000; Yan and Viraraghavan, 2003; Martínez et al., 2006; Jonglertjunya, 2008). However, a reduction of removal efficiency beyond $\mathrm{pH} 6$ has been reported due to a decrease in solubility and precipitation of the metal ions (Kwok and Higuchi, 1989). Hence, the study of $\mathrm{pH} 6$ influence towards the adsorption of $\mathrm{Pb}$ in this study was removed as the $\mathrm{Pb}$ ions also showed precipitation at $\mathrm{pH} 6$. On the other hand, there are several studies that report on a higher $\mathrm{pH}$ (alkaline conditions) enhancing the removal of lead ions by using Moringa oleifera pods and $A$. niger strains (Zayed et al., 1998; Zhu et al., 1999). This clearly suggests that different types of biomass and fungal strains have a different affinity towards $\mathrm{Pb}$ ions and in this study, Pestalotiopsis sp. favours low $\mathrm{pH}$ conditions for adsorption of $\mathrm{Pb}$ ions. As mentioned, our results also showed that dead fungal biomass has a significantly higher removal efficiency (Table 2) and our results are supported by DeBusk et al., (1995) who observed a similar trend in their study. The increase of adsorption for metal ions by dead biomass may be due to the fact that dead fungal biomass has a higher surface area when the cell is ruptured. Besides, dead biomass is not influenced as much by external factors such as the difference of $\mathrm{pH}$ as compared to live biomass (Modak and Natarajan, 1995). In addition, among the possible mechanisms of metal binding towards the fungal biomass, is the intracellular complexation with proteins such as metallothioneins and phytocheelatins (Cenis, 1992). 
Table 2: Paired t-test statistical analysis on the removal efficiency of chromium, lead, and zinc ions by live and dead Pestalotiopsis sp. biomass under $\mathrm{pH}$ condition 4-6.

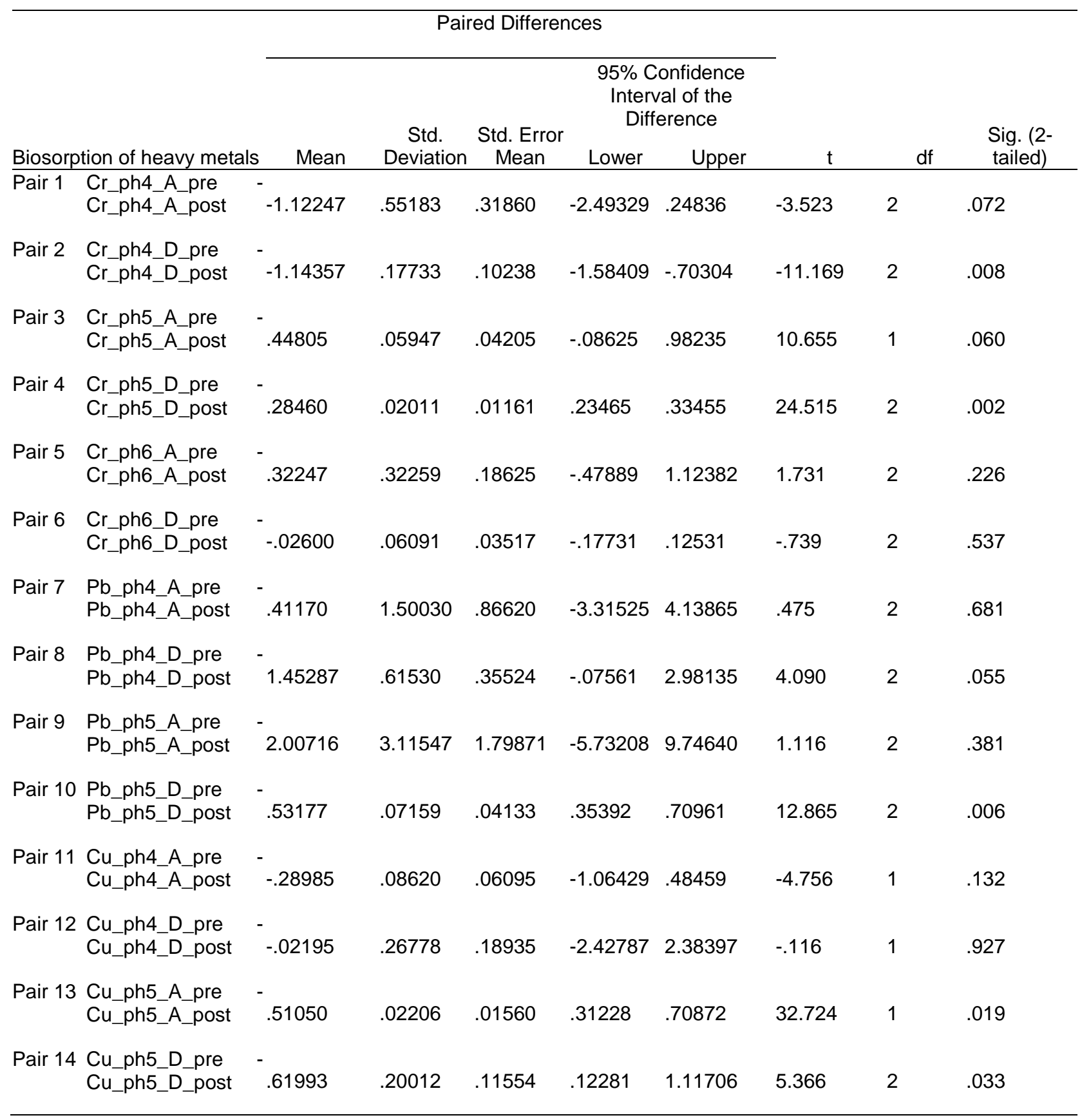




\section{Biosorption of copper ions using encapsulated Ca- alginate fungal biomass}

Based on the findings on $\mathrm{Cu}$ ions removal, the highest removal efficiency was reported by encapsulated dead Pestalotiopsis sp. biomass at $\mathrm{pH} 5$, with a removal efficiency of $14.50 \%$. A reduction of $4.22 \%$ removal efficiency was reported by the encapsulated live fungal biomass under the same $\mathrm{pH}$ condition. However, both the encapsulated live and dead fungal biomass were not able to remove $\mathrm{Cu}$ ions from the solution at $\mathrm{pH} 4$ (Table 1). According to the paired t-test analysis, $\mathrm{pH} 5$ showed a statistically significant impact on the removal of $\mathrm{Cu}$ ions by both encapsulated live Pestalotiopsis $\mathrm{sp}$. ( $\mathrm{t}(1)=$ 32.724, $\mathrm{p}<0.05)$ and dead biomass $(\mathrm{t}(2)=5.316, \mathrm{p}<$ 0.05 ) as shown in Table 2. This suggests that low $\mathrm{pH} 5$ condition enables Pestalotiopsis sp. of $\mathrm{Cu}$ ions efficiently, similarly as reported by Bayramoğlu, Bektaş and Arıca (2003) in which the encapsulated Trametes versicolor favours the acidic $\mathrm{pH}$ condition in the removal of $\mathrm{Cu}$ ions. However, the observed non-removal efficiency at $\mathrm{pH} 4$ can possibly be further studied by investigating other suitable materials of encapsulation such as the carboxymethylcellulose (CMC) bead and polysulfone matrix which may further enhance the biosorption ability.

\section{Efficiency removal of $\mathrm{Cr}, \mathrm{Pb}$, and $\mathrm{Cu}$ between live and dead fungal biomass at different $\mathrm{pH}$ levels}

It is noted to highlight that there is a statistically significant difference among the efficiency removal of heavy metal ions (a) $\mathrm{Cr}$ (b) $\mathrm{Pb}$ and (c) $\mathrm{Cu}$ when treated with different $\mathrm{pH}$ levels by encapsulated live and dead Pestalotiopsis sp. biomass as determined by one-way ANOVA and encapsulated Pestalotiopsis sp. shows a significant removal efficiency of $\mathrm{Cr}$ ions in this study $(F(3,7)=5.969$, $p=0.024$ ) as reported in Table 3. A Tukey post hoc test showed that the efficiency to remove $\mathrm{Cr}$ ions was statistically higher at level $\mathrm{pH} 5$ by encapsulated dead Pestalotiopsis sp. biomass as compared to level $\mathrm{pH} 4$ condition $(0.2800 \pm 0.2, p=0.044)$ in this study.

\section{Proteomic analysis}

The identification of protein interest was done using MALDI-TOF (conducted at Agro-Biotechnology Institute, Kuala Lumpur). The five identified proteins of interest are summarized in Table 4. The identification of proteins is based on the UniProt database and the representative 2$\mathrm{DE}$ gel of proteins from Pestalotiopsis sp. with treatment of $\mathrm{Cr}, \mathrm{Pb}, \mathrm{Zn}$, and $\mathrm{Cu}$ are shown in Figure 1-4 respectively.

Based on the proteins of interest identified (Table 4), it is noteworthy to highlight that protein MRP homolog was among the newly induced proteins detected under the treatment of $\mathrm{Pb}$ in the case of Pestalotiopsis sp. The protein MRP homolog was found to be one of the multidrug resistance proteins (Borst et al., 1999). In this study, the protein MRP homolog was observed to be upregulated at a 3.6 fold against the control treatment. This
Table 3: ANOVA statistical analysis on the chromium, lead and copper metal ions removal efficiency between live and dead Pestalotiopsis sp. under pH condition 4 -6.

\begin{tabular}{|c|c|c|c|c|c|c|}
\hline & & $\begin{array}{l}\text { Sum of } \\
\text { Squares }\end{array}$ & $\mathrm{df}$ & $\begin{array}{l}\text { Mean } \\
\text { Square }\end{array}$ & $\mathrm{F}$ & Sig. \\
\hline \multirow[t]{3}{*}{$\mathrm{Cr}$} & $\begin{array}{l}\text { Between } \\
\text { Groups }\end{array}$ & 1.731 & 3 & .577 & 5.969 & .024 \\
\hline & $\begin{array}{l}\text { Within } \\
\text { Groups }\end{array}$ & .677 & 7 & .097 & & \\
\hline & Total & 2.407 & 10 & & & \\
\hline \multirow[t]{3}{*}{$\overline{\mathrm{Pb}}$} & $\begin{array}{l}\text { Between } \\
\text { Groups }\end{array}$ & 2.526 & 3 & .842 & 2.344 & .149 \\
\hline & $\begin{array}{l}\text { Within } \\
\text { Groups }\end{array}$ & 2.873 & 8 & .359 & & \\
\hline & Total & 5.399 & 11 & & & \\
\hline \multirow[t]{3}{*}{$\mathrm{Cu}$} & $\begin{array}{l}\text { Between } \\
\text { Groups }\end{array}$ & .278 & 3 & .093 & 5.438 & .050 \\
\hline & $\begin{array}{l}\text { Within } \\
\text { Groups }\end{array}$ & .085 & 5 & .017 & & \\
\hline & Total & .363 & 8 & & & \\
\hline
\end{tabular}

suggests that the protein MRP homolog acts as a resistance mechanism of the fungi towards the heavy metal by pumping extra metals out of the cells. Other studies have reported the same mechanism in which the role of the MRP1 in transfection experiments of the cDNA encoding human MRP1 into human tumour cells have shown that the efflux pump ability does not only mediate outwardly transport of anticancer drugs, but may also react with genotoxic heavy metals like antimony and arsenite (Cole et al., 1994). Besides, the overexpression of the efflux pump MRP1 was also demonstrated in GLC4/Sb30 cells at both the mRNA and protein level (Vernhet et al., 1999). Thus, the finding of up-regulated MRP in the presence of lead exposure highlights its essential role in responding to metal toxicity. Multidrug resistance proteins could possibly be used in genetically modified microbes to confer higher resistance towards heavy metal and to enhance bioremediation. Besides, the down-regulation of protein tryptophan synthase alpha chain under the treatment of both $\mathrm{Pb}$ and $\mathrm{Zn}$ could suggest that the metabolic pathways in the case of Pestalotiops sp. was inhibited. This is due to the fact that protein trytophan synthase alpha chain was observed to be down-regulated at a 2-fold against the control treatment in the treatment of $\mathrm{Pb}$ as well as the $\mathrm{Zn}$ treatment. This protein is involved in the aldol cleavage of indoleglycerol phosphate to indole and glyceraldehyde 3phosphate. The role of indole includes spore formation, plasmid stability, drug resistance, biofilm formation and virulence (Lee and Lee, 2010) while glyceraldehyde 3phosphate is an intermediate in various central metabolic pathways and produced in the pentose phosphate pathway (Cronín et al., 1989). A study by Hsiao et al. (2008) demonstrated that increased tryptophan (Trp) levels lead to the Arabidopsis thaliana plant becoming less accessible to cadmium due to a decreased cadmium transport and subsequent reduction in the accumulation 
of cadmium. Taken together, the present study showing the down-regulation of the tryptophan synthase alpha chain under the treatment of heavy metal $\mathrm{Pb}$ and $\mathrm{Zn}$ indicates that the protein is affected in response to heavy metal stress in the fungal communities, but, with the overexpression of the tryptophan protein, it may facilitate in high tolerance towards heavy metal and hence provide new horizons in metabolic engineering for Trp mechanisms towards heavy metal response. In addition, 4-hydroxy-3-methylbut-2-enyl diphosphate reductase (LytB) was found to be down-regulated at a 2.2 fold and 3.2 fold in the treatment of $\mathrm{Pb}$ and $\mathrm{Zn}$, respectively. 4- hydroxy-3-methylbut-2-enyl diphosphate reductase is the last enzyme for isoprenoid biosynthesis which catalyzes the conversion of 1-hydroxy-2-methyl-2-(E)-butenyl 4diphosphate into isopentenyl diphosphate (IPP) and dimethylallyl diphosphate (DMAPP) in the methylerythritol 4-phosphate pathway (MEP) (Wolff et al., 2003). The protein is absent in mammalian systems and the pathway was genetically validated in pathogenic organisms such as the Plasmodium falciparum and Mycobacterium tuberculosis (Hale et al., 2012).

Table 4: The up-regulated and down-regulated protein spots of Pestalotiopsis sp. in response to the heavy metal treatment.

\begin{tabular}{|c|c|c|c|c|c|}
\hline $\begin{array}{l}\text { Spot } \\
\text { no./ID }\end{array}$ & Accession no. & Protein ID & Putative function & $\begin{array}{l}\text { Protein } \\
\text { molecular } \\
\text { weight }\end{array}$ & Protein P.I. \\
\hline 800 & MRP_RICFE & $\begin{array}{l}\text { Protein mnp } \\
\text { homolog }\end{array}$ & ATP binding & 35441 & 7.8 \\
\hline 651 & TRPA_ACAM1 & $\begin{array}{l}\text { Tryptophan } \\
\text { synthase } \\
\text { alpha chain }\end{array}$ & $\begin{array}{c}\text { alpha subunit responsible for aldol } \\
\text { cleavage of indoleglycerol phosphate } \\
\text { to indole and glyceraldehyde 3- } \\
\text { phosphate }\end{array}$ & 28835 & 4.8 \\
\hline 530 & ISPH_ALCBS & $\begin{array}{l}\text { 4-hydroxy-3- } \\
\text { methylbut-2- } \\
\text { enyl } \\
\text { diphosphate } \\
\text { reductase }\end{array}$ & $\begin{array}{l}\text { converts 1-hydroxy-2-methyl-2-(E)- } \\
\text { butenyl 4-diphosphate into } \\
\text { isopentenyl diphosphate (IPP) and } \\
\text { dimethylallyl diphosphate (DMAPP) }\end{array}$ & 34523 & 5.1 \\
\hline 932 & HEM1_METB6 & $\begin{array}{l}\text { Glutamyl- } \\
\text { tRNA } \\
\text { reductase }\end{array}$ & $\begin{array}{l}\text { catalyzes NADPH-dependent } \\
\text { reduction of glutamyl-tRNA(Glu) to } \\
\text { glutamate 1-semialdehyde (GSA) }\end{array}$ & 46258 & 5.9 \\
\hline 1173 & SYV_AROAE & $\begin{array}{l}\text { Valine--tRNA } \\
\text { ligase }\end{array}$ & $\begin{array}{l}\text { catalyzes attachment of valine to } \\
\text { tRNA(Val). As ValRS can } \\
\text { inadvertently accommodate and } \\
\text { process structurally similar amino } \\
\text { acids such as threonine, to avoid } \\
\text { such errors, it has a "posttransfer" } \\
\text { editing activity that hydrolyzes } \\
\text { mischarged Thr-tRNA(Val) in a } \\
\text { tRNA-dependent manner }\end{array}$ & 107751 & 5.5 \\
\hline
\end{tabular}

Due to its absence in the mammalian pathway, the enzymes found in the MEP pathway provide novel targets for the development of antimicrobial chemotherapeutics and herbicides. Besides, the enzyme was also identified as one of the components in penicillin tolerance (Gustafson et al., 1993). The present study identifies LytB as a newly-expressed protein found upon $\mathrm{Pb}$ and $\mathrm{Zn}$ exposure. Hence, the down-regulation of the protein implies that the enzyme is metal-sensitive and gives a new line of evidence that the biosynthesis of isoprenoid can be affected due to the sensitivity of the enzyme in response to heavy metal stress.

Another noteworthy finding to highlight is the detection of enzyme glutamyl-tRNA reductase during the treatment with $\mathrm{Zn}$. The enzyme glutamyl-tRNA reductase (GluTR reductase) was reported to be down-regulated at a 3-fold and a similar trend has been observed in a study by Moser et al. (1999) who reported that the presence of heavy metal compounds such as $\mathrm{PbCl}_{2}, \mathrm{PtCl}_{4}, \mathrm{KdPCl}_{4}$, and $\mathrm{Zn}(\mathrm{II})$ inhibit the GluTR reductase enzyme in Methanopyrus kandleri. It is interesting to note that the enzyme is generally found in plant, algae and most bacteria involved in the C5 pathway of ALA synthesis (Schubert et al., 2002). This may give an indication that the gene from the plant may have incorporated into the endophytic fungi and this give rise to another interaction between plant and endophytes that can be further studied. Another protein detected is the Valine-tRNA ligase enzyme. The valine-tRNA ligase enzyme was found to be up regulated at a 2 -fold against the control 
Malays. J. Microbiol. Vol 15(7) 2019, pp. 505-517

DOI: http://dx.doi.org/10.21161/mjm.180037

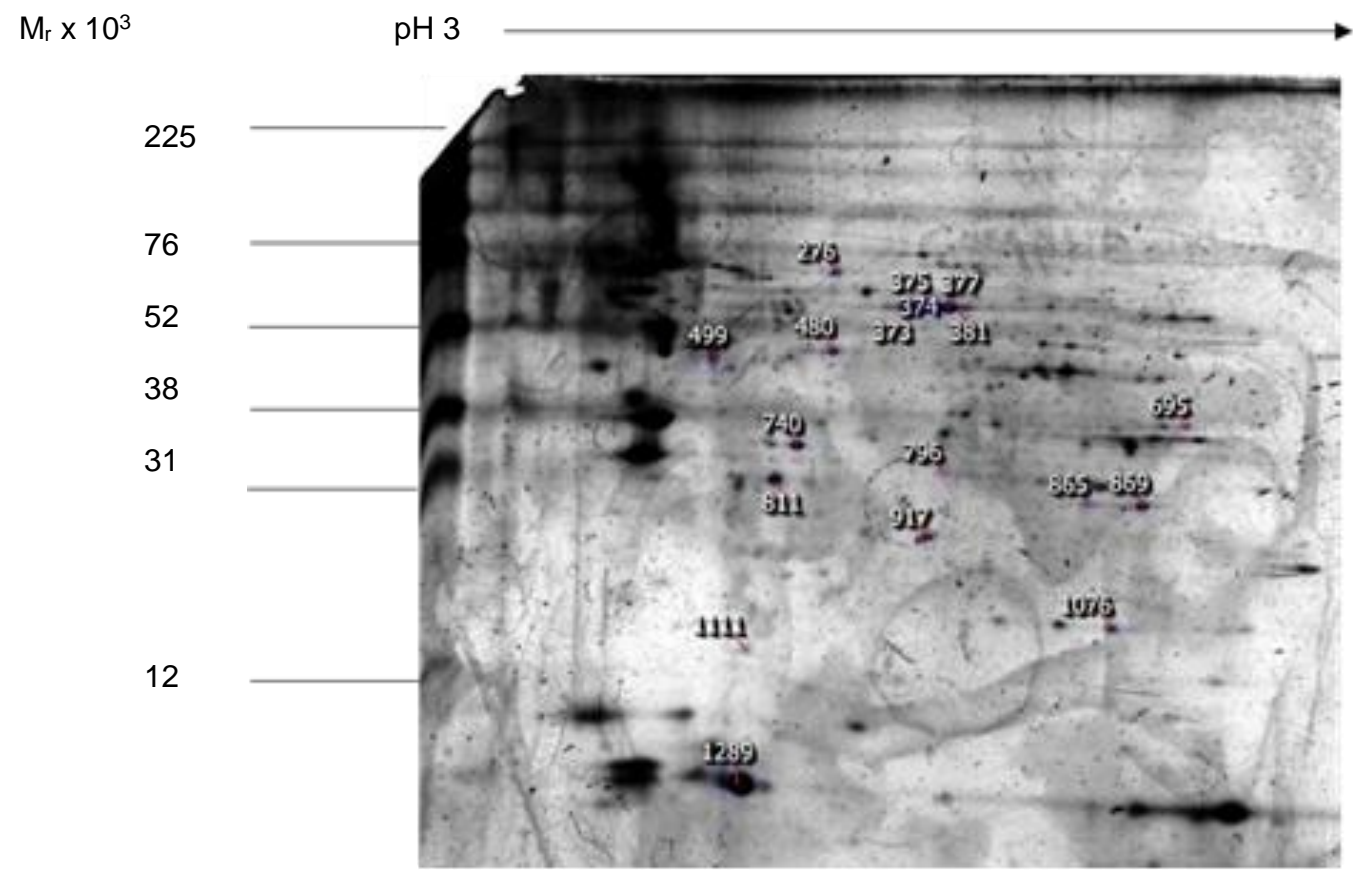

Figure 1: Representative of silver stained 2-DE gel of proteins from Pestalotiopsis sp. with treatment of $\mathrm{Cr}$ metal ion. Extracted proteins $(50 \mu \mathrm{g})$ proteins were loaded on a $13 \mathrm{~cm}$ non-linear IPG strip (pH 3-10) for IEF, following electrophoresis of $12 \%$ SDS-PAGE. The different expression spots present at the position of arrows are compared with the control.

$\operatorname{Mr} \times 10^{3}$

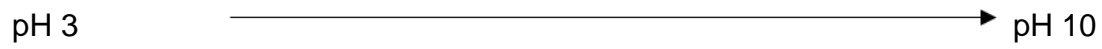

225

76

52

38

31

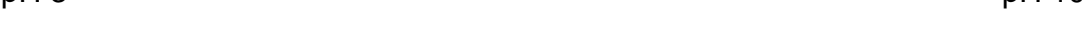

12

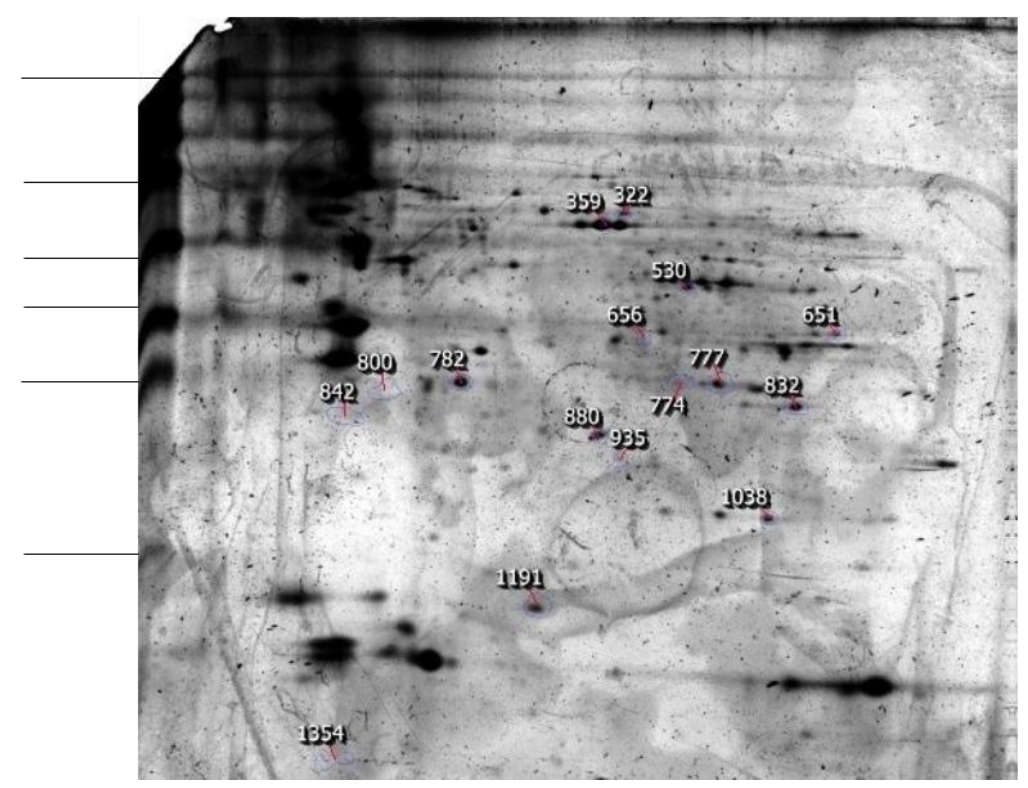

Figure 2: Representative of silver stained 2-DE gel of proteins from Pestalotiopsis sp. with treatment of $\mathrm{Pb}$ metal ion. Extracted proteins $(50 \mu \mathrm{g})$ proteins were loaded on a $13 \mathrm{~cm}$ non-linear IPG strip (pH 3-10) for IEF, following electrophoresis of $12 \%$ SDS-PAGE. The different expression spots present at the position of arrows are compared with the control. 
Malays. J. Microbiol. Vol 15(7) 2019, pp. 505-517

DOI: http://dx.doi.org/10.21161/mjm.180037

$\operatorname{Mr} \times 10^{3}$

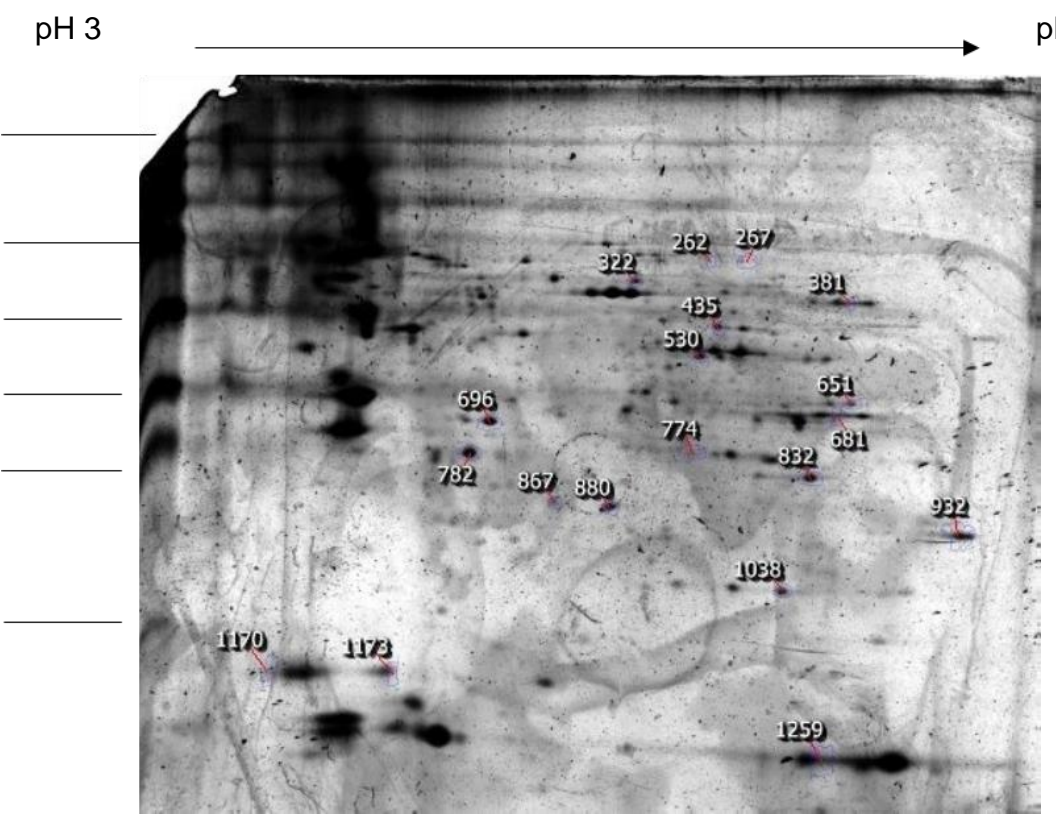

Figure 3: Representative of silver stained 2-DE gel of proteins from Pestalotiopsis sp. with treatment of $\mathrm{Zn}$ metal ion. Extracted proteins $(50 \mu \mathrm{g})$ proteins were loaded on a $13 \mathrm{~cm}$ non-linear IPG strip $(\mathrm{pH} 3-10)$ for IEF, following electrophoresis of $12 \%$ SDS-PAGE. The different expression spots present at the position of arrows are compared with the control.

$\operatorname{Mr} \times 10^{3}$

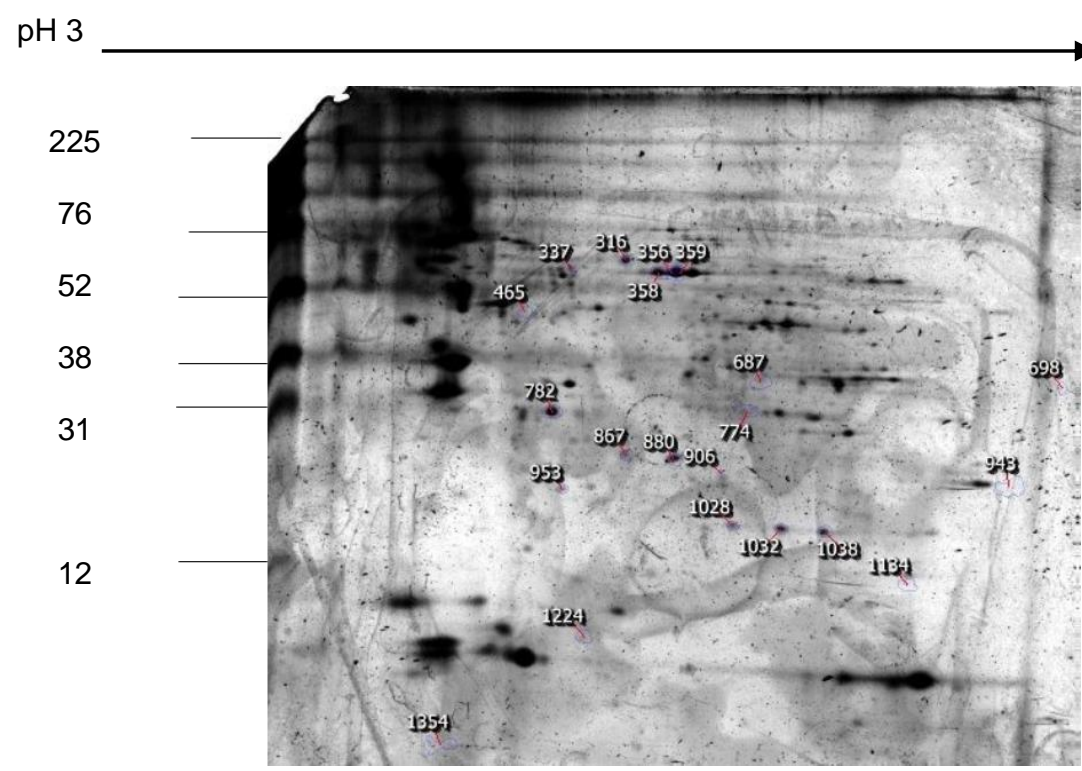

Figure 4: Representative of silver stained 2-DE gel of proteins from Pestalotiopsis sp. with treatment of Cu metal ion. Extracted proteins $(50 \mu \mathrm{g})$ proteins were loaded on a $13 \mathrm{~cm}$ non-linear IPG strip (pH 3-10) for IEF, following electrophoresis of $12 \%$ SDS-PAGE. The different expression spots present at the position of arrows are compared with the control. 
response to the presence of heavy metals. It seems that the enzyme may be contributing to the defense mechanism against $\mathrm{Zn}$ in Pestalotiopsis sp. due to the observed high up-regulation level.

\section{CONCLUSION}

Both encapsulated live and dead Pestalotiopsis sp. fungal biomass showed ability in sequestering and removing heavy metal ions from solution. The dead encapsulated Pestalotiopsis sp. fungal biomass shows significant higher efficiency in removing $\mathrm{Cr}$ metal ion as compared to removal of $\mathrm{Pb}, \mathrm{Cu}$ and $\mathrm{Zn}$ ions at $\mathrm{pH} 5$ and this may suggest that active metabolism such as the efflux mechanism of the cell may be shut off in dead cells which may promote higher affinity of metal accumulation within the cell membrane or cell body. The influence of $\mathrm{pH}$ in the biosorption process has shown that low $\mathrm{pH}$ (acidic) conditions favour the removal of metal ions by the heavymetal resistant Pestalotiopsis sp. It is interesting to note that different types of biomass and fungal strains may exhibit different affinity towards the heavy metal ions and hence $\mathrm{pH}$ study is crucial in the biosorption processes in order to determine the optimum condition for metal removal. This study also reports the down-regulation and up-regulation of selected proteins which provided an initial insight into the mechanisms involved in the biosorption and defense of heavy metal.

\section{ACKNOWLEDGEMENT}

The authors would like to thank the Sarawak Forestry Department for their kind permission to conduct research at the Kuching Wetlands National Park (Permit No. NCCD, 907.4.4(Jld.9)-77 and Park Permit No 142/2013). We also thank the Sarawak Biodiversity Centre for their kind permission to conduct research (Permit No. SBCRA-0092-MM). This project was financially supported by MyBrain15 sponsorship programme by the Malaysian Ministry of Education, and Postgraduate Fee Discount Scheme by Swinburne University of Technology, Sarawak. The research leading to these results has received funding from Swinburne Sarawak under grant agreement no. SSRG/FECS/2013/2/4.

\section{REFERENCES}

Aksu, Z., Sag, Y. and Kutsal, T. (1992). The biosorpnon of Copperod by $C$. vulgaris and $Z$. ramigera. Environmental Technology 13(6), 579-586.

Al-Qodah, Z. (2006). Biosorption of heavy metal ions from aqueous solutions by activated sludge. Desalination 196(1), 164-176.

Annadurai, G., Juang, R. S. and Lee, D. J. (2002). Use of cellulose-based wastes for adsorption of dyes from aqueous solutions. Journal of Hazardous Materials 92(3), 263-274.

Arıca, M. Y., Kaçar, Y. and Genç, Ö. (2001). Entrapment of white-rot fungus Trametes versicolor in Ca-alginate beads: Preparation and biosorption kinetic analysis for cadmium removal from an aqueous solution. Bioresource Technology 80(2), 121-129.

Bai, S. and Abraham, T. E. (2001). Biosorption of $\mathrm{Cr}$ (VI) from aqueous solution by Rhizopus nigricans. Bioresource Technology 79(1), 73-81.

Bayramoğlu, G., Bektaş, S. and Arıca, M. Y. (2003). Biosorption of heavy metal ions on immobilized whiterot fungus Trametes versicolor. Journal of Hazardous Materials 101(3), 285-300.

Bayramoğlu, G., Denizli, A., Bektas, S. and Arica, M. Y. (2002). Entrapment of Lentinus sajor-caju into $\mathrm{Ca}-$ alginate gel beads for removal of $\mathrm{Cd}$ (II) ions from aqueous solution: preparation and biosorption kinetics analysis. Microchemical Journal 72(1), 63-76.

Bong, S. W. L., Al-Obaidi, J. R., Rahmad, N., Mujahid, A. and Müller, M. (2017). Polyurethane degradation using endophytic fungi isolated from Nepenthes ampullaria in Sarawak. Malaysian Journal of Microbiology 13(3), 172-179.

Borst, P., Evers, R., Kool, M. and Wijnholds, J. (1999). The multidrug resistance protein family. Biochimica et Biophysica Acta (BBA)-Biomembranes 1461(2), 347357.

Carr, D. S., Spangenberg, W. C. and Chronley, K. (1995). Lead Compounds - Lead Salts, in Kirk-Othmer Encyclopedia of Chemical Technology - Lasers to Mass Spectrometry, $4^{\text {th }}$ ed., Wiley, New York, 1995, pp.132-152.

Cenis, J. (1992). Rapid extraction of fungal DNA for PCR amplification. Nucleic Acids Research 20(9), 2380.

Choo, J., Mohd Sabri, N., Tan, D., Mujahid, A. and Müller, M. (2015). Heavy metal resistant endophytic fungi isolated from Nypa fruticans in Kuching Wetland National Park. Ocean Science Journal 50(2), 445-453.

Chuah, T., Jumasiah, A., Azni, I., Katayon, S. and Choong, S. T. (2005). Rice husk as a potentially lowcost biosorbent for heavy metal and dye removal: An overview. Desalination 175(3), 305-316.

Cimino, G., Passerini, A. and Toscano, G. (2000). Removal of toxic cations and $\mathrm{Cr}$ (VI) from aqueous solution by hazelnut shell. Water Research 34(11), 2955-2962.

Cole, S. P., Sparks, K. E., Fraser, K., Loe, D. W., Grant, C. E., Wilson, G. M. and Deeley, R.G. (1994). Pharmacological characterization of multidrug resistant MRP-transfected human tumor cells. Cancer Research 54(22), 5902-5910.

Congeevaram, S., Dhanarani, S., Park, J., Dexilin, M. and Thamaraiselvi, K. (2007). Biosorption of chromium and nickel by heavy metal resistant fungal and bacterial isolates. Journal of Hazardous Materials 146(1), 270-277.

Cronín, C. N., Nolan, D. P. and Voorheis, H. P. (1989). The enzymes of the classical pentose phosphate pathway display differential activities in procyclic and bloodstream forms of Trypanosoma brucei. FEBS Letters 244(1), 26-30.

DeBusk, T. A., Peterson, J. E. and Reddy, K. R. (1995). Use of aquatic and terrestrial plants for removing 
phosphorus from dairy wastewaters. Ecological Engineering 5(2), 371-390.

Doshi, H., Ray, A. and Kothari, I. (2007). Bioremediation potential of live and dead Spirulina: spectroscopic, kinetics and SEM studies. Biotechnology and Bioengineering 96(6), 1051-1063.

Farooq, U., Kozinski, J. A., Khan, M. A. and Athar, M. (2010). Biosorption of heavy metal ions using wheat based biosorbents- A review of the recent literature. Bioresource Technology 101(14), 5043-5053.

Gadd, G. M. and White, C. (1993). Microbial treatment of metal pollution-a working biotechnology? Trends in Biotechnology 11(8), 353-359.

Gardes, M. and Bruns, T. D. (1993). ITS primers with enhanced specificity for basidiomycetes-application to the identification of mycorrhizae and rusts. Molecular Ecology 2(2), 113-118.

Gustafson, C. E., Kaul, S. and Ishiguro, E. E. (1993). Identification of the Escherichia coli lytB gene, which is involved in penicillin tolerance and control of the stringent response. Journal of Bacteriology 175(4), 1203-1205.

Hale, I., O'Neill, P. M., Berry, N. G., Odom, A. and Sharma, R. (2012). The MEP pathway and the development of inhibitors as potential anti-infective agents. Medicinal Chemistry Communications 3(4), 418-433.

Hao, S. and Hou, J. (2013). Adsorption of $\mathrm{Ni}^{+}$on aminofunctionalized mesoporous silica templated by an anionic surfactant route. Journal of Material Research 28(17), 2325-2331.

Hashem, A. (2006). Amidoximated sunflower stalks (ASFS) as a new adsorbent for removal of $\mathrm{Cu}$ (II) from aqueous solution. Polymer-plastics Technology and Engineering 45(1), 35-42.

Hsiao, P. Y., Su, R. C., Ko, S. S., Tong, C. G., Yang, R. Y. and Chan, M. T. (2008). Overexpression of Arabidopsis thaliana tryptophan synthase beta 1 (AtTSB1) in Arabidopsis and tomato confers tolerance to cadmium stress. Plant, Cell and Environment 31(8), 1074-1085.

Iram, S., Parveen, K., Usman, J., Nasir, K., Akhtar, N., Arouj, S. and Ahmad, I. (2012). Heavy metal tolerance of filamentous fungal strains isolated from soil irrigated with industrial wastewater. Biologija 58(3), 107-116.

Jonglertjunya, W. (2008). Biosorption of lead (II) and copper (II) from aqueous solution. Chiang Mai Journal of Science 35, 69-81.

Kingsmore, S. F. and Saunders, C. J. (2011). Deep sequencing of patient genomes for disease diagnosis: When will it become routine? Science translational medicine 3(87), 87ps23.

Kratochvil, D. and Volesky, B. (1998). Advances in the biosorption of heavy metals. Trends in Biotechnology 16(7), 291-300.

Kojuncu, Y., Bundalevska, J. M., Ay, U. and Cundeva, K. (2004). Atomic absorption spectrometry determination of $\mathrm{Cd}, \mathrm{Cu}, \mathrm{Fe}, \mathrm{Ni}, \mathrm{Pb}, \mathrm{Zn}$, and $\mathrm{Tl}$ traces in seawater following flotation separation. Separation Science and Technology 38(11), 2751-2765.

Kwok, S. and Higuchi, R. (1989). Avoiding false positives with PCR. Nature 339, 237-238.

Lee, J. H. and Lee, J. (2010). Indole as an intercellular signal in microbial communities. FEMS Microbiology reviews 34(4), 426-444.

Lesage, E., Rousseau, D., Meers, E., Van de Moortel, A., Du Laing, G., Tack, F., De Pauw, N. and Verloo, M. (2007). Accumulation of metals in the sediment and reed biomass of a combined constructed wetland treating domestic wastewater. Water, Air, and Soil Pollution 183(1-4), 253-264.

Li, X., Bai, T., Li, Y., Ruan, X. and Li, H. (2013). Proteomic analysis of Fusarium oxysporum $f$. sp. cubense tropical race 4-inoculated response to Fusarium wilts in the banana root cells. Proteome Science 11(1), 1-14.

Martínez, M., Miralles, N., Hidalgo, S., Fiol, N., Villaescusa, I. and Poch, J. (2006). Removal of lead (II) and cadmium (II) from aqueous solutions using grape stalk waste. Journal of Hazardous Materials 133(1), 203-211.

Modak, J. and Natarajan, K. (1995). Biosorption of metals using nonliving biomass- A review. Minerals and Metallurgical Processing 12(4), 189-196.

Mohanty, K., Jha, M., Meikap, B. and Biswas, M. (2006). Biosorption of $\mathrm{Cr}(\mathrm{VI})$ from aqueous solutions by Eichhornia crassipes. Chemical Engineering Journal 117(1), 71-77.

Mohapatra, P. K. (2011). Textbook of Environmental Biotechnology, IK International Publishing House. pp 614.

Moser, J., Lorenz, S., Hubschwerlen, C., Rompf, A. and Jahn, D. (1999). Methanopyrus kandleri glutamyltRNA reductase. Journal of Biological Chemistry 274(43), 30679-30685.

Ozdemir, G., Ceyhan, N., Ozturk, T., Akirmak, F. and Cosar, T. (2004). Biosorption of chromium (VI), cadmium (II) and copper (II) by Pantoea sp. TEM18. Chemical Engineering Journal 102(3), 249-253.

Park, D., Yun, Y. S., Jo, J. H. and Park, J. M. (2005). Mechanism of hexavalent chromium removal by dead fungal biomass of Aspergillus niger. Water Research 39(4), 533-540.

Park, D., Yun, Y. S. and Park, J. M. (2010). The past, present, and future trends of biosorption. Biotechnology and Bioprocess Engineering 15(1), 86102.

Rizzo, J. M. and Buck, M. J. (2012). Key principles and clinical applications of "next-generation" DNA sequencing. Cancer Prevention Research 5(7), 887900.

Sanger, F., Nicklen, S. and Coulson, A. R. (1977). DNA sequencing with chain-terminating inhibitors', Proceedings of the National Academy of Sciences. 74(12), 5463-5467.

Schubert, W. D., Moser, J., Schauer, S., Heinz, D. W. and Jahn, D. (2002). Structure and function of glutamyl-tRNA reductase, the first enzyme of 
tetrapyrrole biosynthesis in plants and prokaryotes. Photosynthesis Research 74(2), 205-215.

Seo, D. C., Yu, K. and DeLaune, R. D. (2008). Comparison of monometal and multimetal adsorption in Mississippi River alluvial wetland sediment: Batch and column experiments. Chemosphere 73(11), 1757 1764.

Sia, E., Yeo, J., Wong, J., Choo, J., Wong, C., Mujahid, A. and Müller, M. (2017). Screening of endophytic fungi for biofuel feedstock production using palm oil mill effluent as a carbon source. Malaysian Journal of Microbiology 13(3), 203-209.

Skowronski, T., Pirszel, J. and Pawlik-Skowronska, B. (2001). Heavy metal removal by the waste biomass of Penicillium chrysogenum. Water Quality Research Journal of Canada 36(4), 793-803.

Tee, T. W. and Khan, A. R. M. (1988). Removal of lead, cadmium and zinc by waste tea leaves. Environmental Technology 9(11), 1223-1232.

Tewari, N., Vasudevan, P. and Guha, B. (2005). Study on biosorption of $\mathrm{Cr}(\mathrm{VI})$ by Mucor hiemalis. Biochemical Engineering Journal 23(2), 185-192.

Vernhet, L., Courtois, A., Allain, N., Payen, L., Anger, J. P., Guillouzo, A. and Fardel, O. (1999). Overexpression of the multidrug resistance-associated protein (MRP1) in human heavy metal-selected tumor cells. FEBS Letters 443(3), 321-325.

Veglio, F. and Beolchini, F. (1997). Removal of metals by biosorption: A review. Hydrometallurgy 44(3), 301316.

Vijayaraghavan, K. and Yun, Y. S. (2008). Bacterial biosorbents and biosorption. Biotechnology Aadvances 26(3), 266-291.

Wang, J. and Chen, C. (2009). Biosorbents for heavy metals removal and their future. Biotechnology Advances 27(2), 195-226.

Wolff, M., Seemann, M., Bui, B. T. S., Frapart, Y., Tritsch, D., Estrabot, A. G., RodríguezConcepción, M., Boronat, A., Marquet, A. and Rohmer, M. (2003). Isoprenoid biosynthesis via the methylerythritol phosphate pathway: The (E)-4hydroxy-3-methylbut-2-enyl diphosphate reductase (LytB/lspH) from Escherichia coli is a [4Fe-4S] protein. FEBS Letters 541(1), 115-120.

Yan, G. and Viraraghavan, T. (2003). Heavy-metal removal from aqueous solution by fungus Mucor rouxii. Water research 37(18), 4486-4496.

Ye, Z., Baker, A., Wong, M. and Willis, A. (1997). Zinc, lead and cadmium tolerance, uptake and accumulation by the common reed, Phragmites australis (Cav.) Trin. ex Steudel. Annals of Botany 80(3), 363-370.

Yetis, U., Dolek, A., Dilek, F.B. and Ozcengiz, G. (2000). The removal of $\mathrm{Pb}$ (II) by Phanerochaete chrysosporium. Water Research 34(16), 4090-4100.

Zayed, A., Gowthaman, S. and Terry, N. (1998). Phytoaccumulation of trace elements by wetland plants: I. Duckweed. Journal of Environmental Quality 27(3), 715-721.
Zhang, Y., Zhang, S., Liu, X., Wen, H. and Wang, M. (2010). A simple method of genomic DNA extraction suitable for analysis of bulk fungal strains. Letters in Applied Microbiology 51(1), 114-118.

Zhu, Y., Zayed, A., Qian, J., De Souza, M. and Terry, N. (1999). Phytoaccumulation of trace elements by wetland plants: II. Water hyacinth. Journal of Environmental Quality 28(1), 339-344. 